\title{
THE CLINICAL SYNDROMES AND SURGICAL TREATMENT OF THORACIC INTERVERTEBRAL DISC PROLAPSE
}

\author{
M. K. D. Benson and D. P. Byrnes, London, England \\ From the National Hospital for Nervous Diseases and Atkinson Morley's Hospital, London
}

\begin{abstract}
Doubt remains as to the safest surgical approach to the prolapsed thoracic intervertebral disc. Laminectomy, lateral rhachotomy and the transthoracic approach all have their protagonists.

Twenty-two patients from the National Hospital for Nervous Diseases, Queen Square, and Atkinson Morley's Hospital have been reviewed. Their clinical presentation is discussed and the ancillary aids to diagnosis assessed. The diagnostic value of disc space calcification is stressed, and the use of air myelography as an adjunct to positive contrast myelography is noted.

Fifteen patients were subjected to laminectomy, and seven to lateral rhachotomy. Each group contained patients with a wide range of neurological deficit. Six of the patients who underwent laminectomy were improved, two were unchanged, six deteriorated and one died. Of the patients who had lateral rhachotomy, six were improved, one was unchanged and none deteriorated. The conclusion is drawn that lateral rhachotomy is a safer procedure.
\end{abstract}

In recent years the gloom which surrounded the condition of thoracic disc protrusion has lightened, in part with improved diagnostic facility, in part with the development of new surgical techniques.

Middleton and Teacher (1911) first drew attention to a patient with paraplegia following heavy lifting. The earliest record of a patient treated by operation was that of Adson in 1922 at the Mayo Clinic, reported by Love and Schorn (1965). A disc protrusion at the sixth thoracic interspace was removed in a woman of sixty.

Early experiences with operation were depressing (Mixter and Barr 1934; Hawk 1936; Love and Kiefer 1950; Müller 1951; Logue 1952). In all their patients operation was by decompressive thoracic laminectomy, either alone or in association with disc removal. The disc removal was either transdural or extradural. It became apparent that those patients who did well after laminectomy were mainly those with lateral disc protrusions; those with central protrusions fared less well. For a midline disc prolapse the posterior laminectomy approach offered the worst access. Perot and Munro (1969), reviewing ninety-one collected cases, found that with the thoracic laminectomy approach forty patients were not improved: indeed, sixteen became paraplegic. Perot further showed that thirty-four of these herniations were lateral and fifty-seven were central. Seventy-six per cent of the patients with lateral protrusions were improved; 44 per cent of the patients with central protrusions were improved.

Costotransversectomy, introduced by Ménard (1900) for the surgical decompression of spinal tuberculosis, was developed further by Seddon (1935) and, as lateral rhachotomy, by Capener (1954), who also stressed its use for conditions other than Pott's disease. Hulme (1960) appears to have been the first to apply this principle to thoracic disc herniation: he described six patients, four of whom showed improvement. Bonney's patient, whose case was reported by Chesterman (1964), showed similar improvement after transient paraplegia. Lateral rhachotomy allows a lateral approach to the protruded disc and its removal with minimal mobilisation of the theca.

The subsequent logical development in approaching the disc space was by the transthoracic route. Following extensive studies on dogs, Crafoord, Hiertonn, Lindblom and Olsson (1958) reported the first right-sided transthoracic disc removal. The patient, with spastic paraparesis complicating a tenth thoracic interspace protrusion, made a complete recovery. Perot and Munro (1969) reported two patients treated by antero-lateral disc removal by right thoracotomy. Ransohoff, Spencer, Siew and Gage (1969) reported three antero-lateral decompressions by left thoracotomy. Improvement was claimed in all patients. Both reports stressed the danger of injuring the artery of Adamkiewicz, the largest of the spinal branches of the intercostal and lumbar vessels, and the main nutrient vessel of the lumbar cord. Ransohoff further recommended pre-operative intercostal angiography to determine the size and level of the artery.

The recent report of Carson, Gumpert and Jefferson (1971) suggested that poor results from thoracic laminectomy were in the main due to inadequate exposure. They operate with the patient in the knee-elbow position, remove the spines and laminae of three vertebrae, transect the erector spinae mass, and remove a considerable portion of the facet joints. They noted that this enabled them to approach the disc space very nearly laterally.

M. K. D. Benson, F.R.C.S., Research Fellow, The Division of Orthopaedic Surgery, School of Medicine, The Center for the Health Sciences, Los Angeles, California 90024, U.S.A.

D. P. Byrnes, F.R.C.S.(I), Johns Hopkins Hospital, 601 North Broadway, Baltimore, Maryland 21205, U.S.A. 
Their results-eleven patients out of fourteen improved, two unaltered and one worse-are clearly impressive.

The type of surgical operation most suited to thoracic disc removal does not appear clear cut. For this reason all patients submitted to operation at the Atkinson Morley's Hospital and the patients of Mr Walsh and Mr Grant at the National Hospital for Nervous Diseases from 1952 to 1974 were reviewed. This series therefore follows that of Logue (1952). Operative exposure has been either by laminectomy or by lateral rhachotomy. There is no experience of transthoracic disc removal. This paper attempts to assess the clinical syndromes resulting from thoracic disc prolapse and to compare thoracic laminectomy with lateral rhachotomy.

\section{CLINICAL MATERIAL}

Twenty-two patients with surgically proven thoracic disc prolapse have been reviewed. There were seven women and fifteen men. Their ages ranged from thirty-three years to sixty-six years, with a mean age of forty-eight years (Fig. 1). The peak incidence of thoracic disc protrusion in the fifth and sixth decades demonstrated in this series is in keeping with most published works. Isolated cases of disc prolapse in children are recorded (Peck 1957).
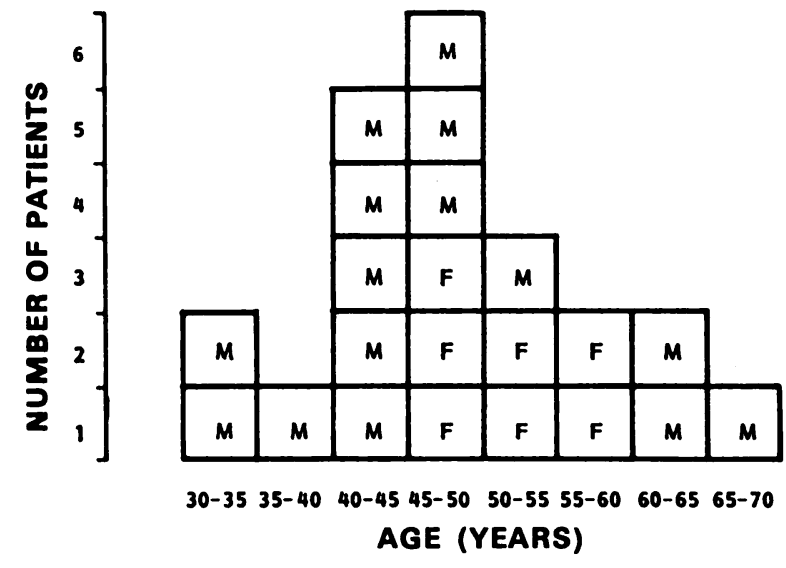

Fig. 1

Age and sex distribution.

Carson, Gumpert and Jefferson (1971) estimate that for a one million population there will be one patient per year who presents with protruded thoracic intervertebral disc. The relative incidence of thoracic disc protrusion by comparison with disc protrusions at all levels is estimated to be about five cases per thousand (Love and Schorn 1965). In ninetynine unselected cadavers Haley and Perry (1950) found two thoracic disc protrusions greater than 4 millimetres. These figures lend credence to the view that thoracic disc herniation should be diagnosed more frequently.

Symptoms - Only eleven patients complained of back pain and this was often poorly localised. The backache typically was not severe and was relieved by rest. When present, however, it invariably preceded the signs of cord compression. Leg pain was common, but followed no specific pattern: most frequently aching pain was felt at one or both knees. Pain at the hip, ankle or foot was also mentioned. The quality of the pain was similarly variable: it was sometimes constant, cramping or spasmodic; it could be dull, burning or lancinating. Onethird of the patients experienced girdle pain. This was always subumbilical, and usually felt at or near the groin. It was always unilateral.

Most patients complained of sensory symptoms other than pain. These were usually of numbness or coldness in the legs. Patients rarely complained of paraesthesiae.

All but one patient complained of weakness or heaviness in the legs. Bilateral weakness was twice as common as unilateral weakness. Eleven patients were able to walk unaided; four could walk with only sticks or crutches; seven were unable to walk.

Two-thirds of the patients had no urinary or bowel symptoms. Only three patients presented with retention of urine. The remainder had noted either hesitancy, urgency or a sensation of incomplete evacuation. One patient with hesitancy also had faecal incontinence.

The length of history ranged from one month to eight years. In the two cases of paraplegia, the paralysis in one occurred gradually over six months, and in the other suddenly and catastrophically after the patient rose from bed. The latter patient had simply had three months of backache. It was noteworthy that although pain fluctuated, weakness was progressive in every patient.

Only two patients attributed their symptoms to heavy lifting, and indeed analysis of occupations revealed no preponderance of heavy manual workers. One woman's symptoms dated from a difficult breech delivery. Four patients had suffered from previous spinal disability. One had mild idiopathic thoracic scoliosis which had required no operation. One patient was achondroplastic. One had suffered from a lumbo-sacral spondylolisthesis and one who had had backache in adolescence was shown to have radiological evidence of old notched epiphysitis.

Examination-Five patients showed a spinal deformity. These included the three patients noted previously with achondroplasia, idiopathic scoliosis and smooth kyphosis resulting from old Scheuermann's disease. One patient had a localised kyphos and the last showed a short scoliosis from the eighth to the twelfth thoracic level. Intercostal muscle wasting was not seen. Localised spinous tenderness was present in half the patients, but paraspinous muscle spasm was not seen.

Power was impaired in all but two patients. The range of deficit covered the full spectrum from mild monoparesis to complete paraplegia. Weakness of the lower abdominal muscles, well demonstrated when the umbilicus is seen to rise as the patient attempts to sit upright, was a frequent observation. In six patients leg weakness was unilateral; in fourteen patients it was bilateral. Proximal and distal muscle groups were usually comparably weak, but in several patients footdrop was the most notable feature.

Most patients were found to have increased muscle tone. In one-third of patients however no abnormality of tone could be demonstrated, and one-the thirty-three-year-old man with sudden complete paraplegia - showed a flaccid paralysis.

In most patients the lower abdominal reflexes were absent, the knee and ankle responses were exaggerated and the plantar responses were extensor.

In only two of the twenty-two patients was sensation normal. Four patients exhibited the Brown-Séquard syndrome. With these exceptions, sensory loss was bilateral. The completeness of the sensory loss varied widely and there appeared to be no pattern in the loss of sensory discrimination. A band of hyperalgesia was rarely demonstrable, even in those patients with girdle pain. The sensory level was typically one to two levels lower than that subsequently demonstrated by myelography and operation.

Investigations-The cerebro-spinal fluid was turbid in 50 per 
cent of the patients; the protein content ranged from 10 to 300 milligrams per cent with a mean value of 79 milligrams. Neither the appearance nor the protein level bore any relation to the severity of the clinical state, nor was it related to the duration of symptoms. significance was the presence of disc calcification (Logue 1952; Arseni and Nash 1960). Ten of the twenty-two patients showed evidence of disc calcification (Fig. 2). In six patients this was solely at the level of the disc prolapse; in the remainder two or more interspaces were involved. Calcification takes

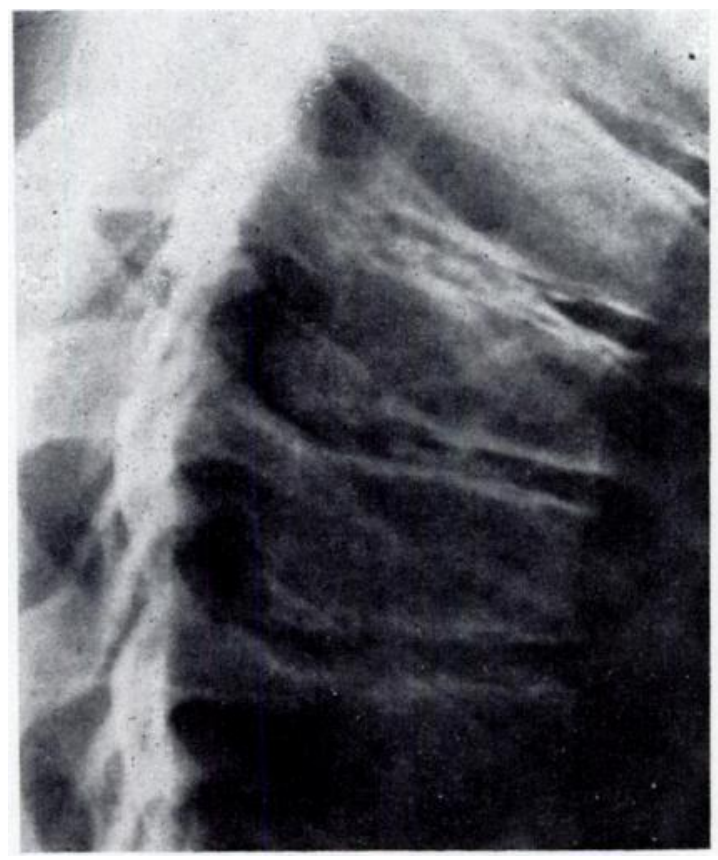

FIG. 2

Lateral radiograph showing calcification of the sixth and seventh thoracic interspaces.

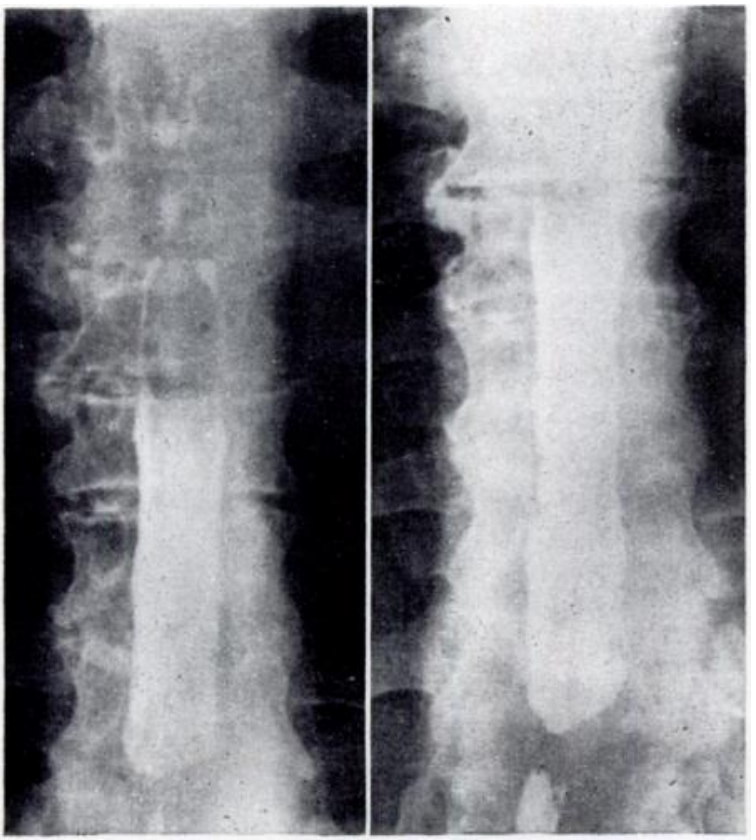

FiG. 3

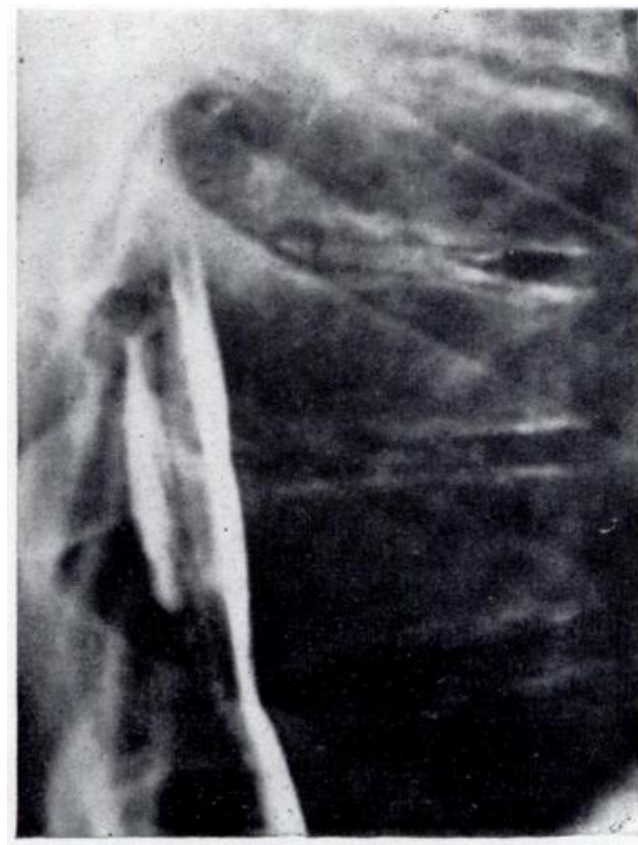

Fig. 4

Positive contrast myelograph showing a central disc protrusion at the sixth thoracic interspace. Calcification is seen at the sixth and seventh interspaces.

Plain radiographs, often with tomography, gave considerable help in establishing the diagnosis. Degenerative changes, manifest by osteophytic lipping, disc space narrowing, apophysial joint narrowing or sclerosis were common findings in this as in any comparable group of patients. Of far greater place in the degenerate nucleus pulposus, and this calcification may be demonstrable within the spinal canal. Logue (1952) showed that in a matched series of 100 cases nuclear calcification was observed in only four patients. Similarly, in twentyfive patients suffering from compression of the thoracic spinal 
cord by neoplasm, such as neurofibromata, meningiomata, and metastatic tumours, again drawn from a similar age group, there were no instances of nuclear calcification.

Myelography is the keystone of diagnosis. When possible this was performed by the lumbar route (Figs. 3 and 4). In four patients it proved impossible to perform a lumbar

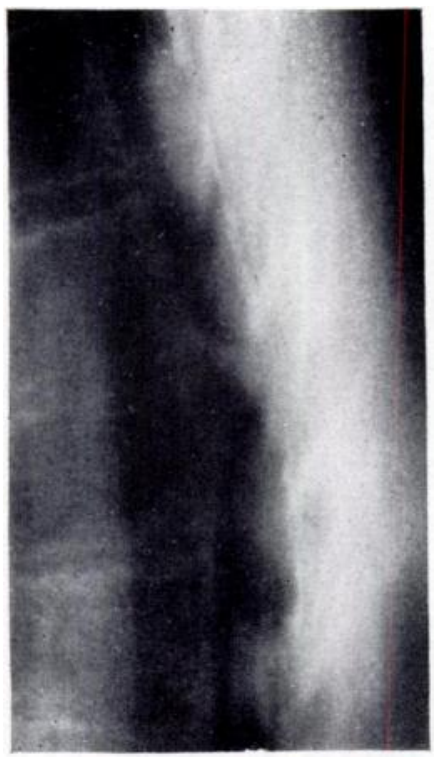

Fig. 5

Lateral tomograph after injection of air, showing a disc protrusion at the sixth interspace.

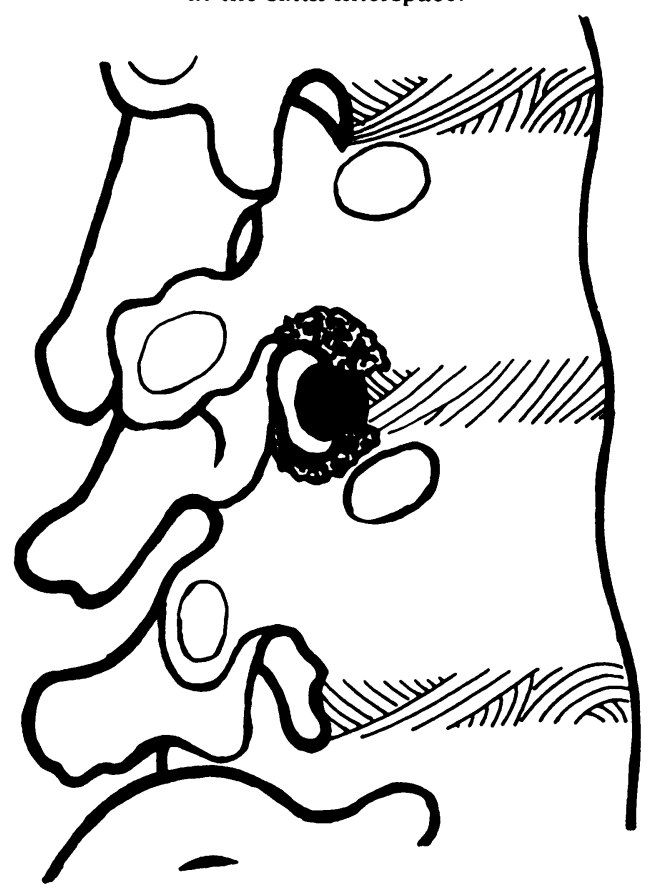

FiG. 7

The exposure by lateral rhachotomy

puncture and Myodil was inserted by the cisternal or the ventricular route. In most patients adequate information was obtained by these means. In three patients, however, the diagnosis remained in doubt and air myelography was performed. Air was inserted by the lumbar route and radiographic definition was improved by lateral and antero-posterior tomography (Fig. 5). Seven patients showed a complete block to the flow of contrast at the level of the disc prolapse. The remaining fifteen patients showed partial blocks. It was noteworthy that the severity of clinical neurological involvement did not correlate with the completeness of the block. The level of the disc protrusion was found most frequently at the ninth thoracic interspace (Fig. 6). Most of the prolapses occurred at the lowest five interspaces and this correlates well

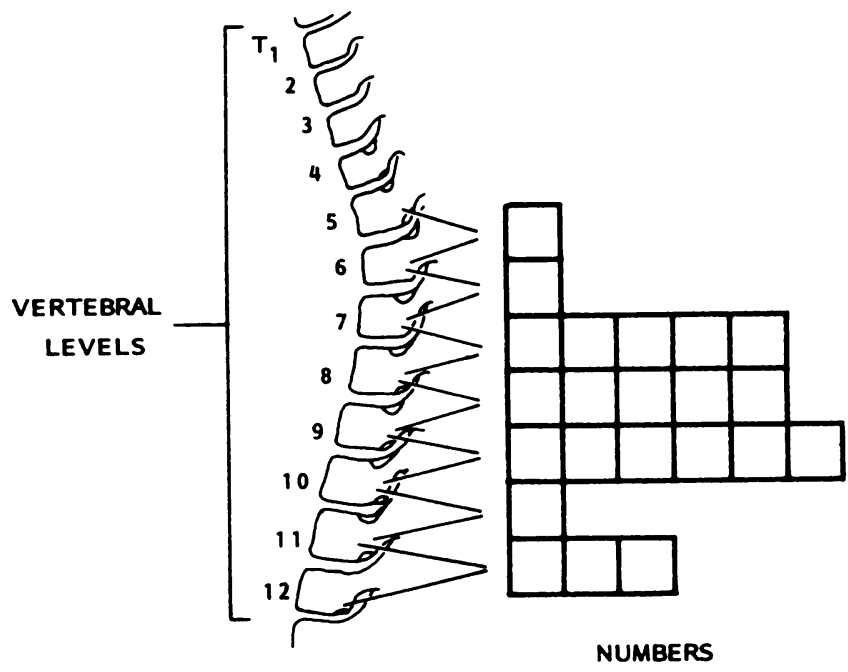

Fig. 6

The incidence of disc prolapse at different spinal levels.

with other published series (Kroll and Reiss 1951; Love and Schorn 1965). There was no instance of multiple disc protrusion, and this indeed seems rare (Svien and Karavitis 1954). It was possible to decide whether the disc protrusion was central or lateral with certainty in only fifteen cases: of these, eight were lateral and seven central. Air myelography was found extremely valuable when the cause of the block could not with reasonable certainty be diagnosed by positive contrast myelography. No complications from air myelography were seen.

Treatment-All patients had been treated conservatively before

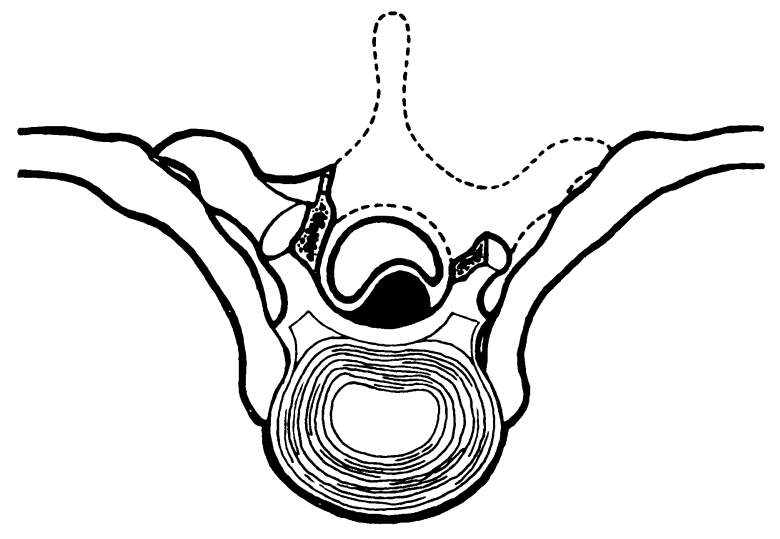

FIG. 8

The exposure by thoracic laminectomy

their referral to the neurological centre. Treatment had included bed rest, physiotherapy, manipulation with and without anaesthesia, and the application of corsets and plaster jackets. Operative treatment in this series was by lateral rhachotomy in seven patients and by thoracic decompressive laminectomy in fifteen. The need for careful pre-operative marking of the level of the protrusion is stressed by the fact that one patient was operated upon initially at the wrong level. 
TABLE I

The Clinical Presentation, Radiographic Findings and Surgical Results in Twenty-two Patients with Thoracic Disc Herniations

\begin{tabular}{|c|c|c|c|c|c|c|c|c|c|c|c|c|c|c|}
\hline \multirow[b]{2}{*}{$\begin{array}{c}\text { Case } \\
\text { number }\end{array}$} & \multirow[b]{2}{*}{$\begin{array}{c}\text { Age } \\
\text { (years) }\end{array}$} & \multirow[b]{2}{*}{ Sex } & \multicolumn{3}{|c|}{ Presenting symptoms } & \multicolumn{4}{|c|}{ Clinical signs } & \multicolumn{2}{|c|}{ Radiography } & \multirow[b]{2}{*}{ Level } & \multirow[b]{2}{*}{ Operation } & \multirow[b]{2}{*}{ Result } \\
\hline & & & Pain & $\begin{array}{l}\text { Weak- } \\
\text { ness }\end{array}$ & Sphincters & $\begin{array}{l}\text { Sensa- } \\
\text { tion }\end{array}$ & Power & $\begin{array}{l}\text { Plant: } \\
\text { refiex }\end{array}$ & tar & $\begin{array}{l}\text { Calci- } \\
\text { fication }\end{array}$ & $\begin{array}{l}\text { Myelo- } \\
\text { graphy }\end{array}$ & & & \\
\hline 1 & 47 & $\mathbf{F}$ & $\begin{array}{c}\text { Back. } \\
\text { Girdle. } \\
\text { Both legs }\end{array}$ & $\begin{array}{l}\text { Both } \\
\text { legs }\end{array}$ & Normal & $\begin{array}{c}\text { Bilateral } \\
\text { loss }\end{array}$ & $\begin{array}{c}\text { Mild } \\
\text { monoparesis }\end{array}$ & $\downarrow \uparrow$ & $\uparrow$ & T.7-8 & $\begin{array}{l}\text { Partial } \\
\text { block }\end{array}$ & T.7-8 & Laminectomy & $\begin{array}{l}\text { Good } \\
\text { recovery }\end{array}$ \\
\hline 2 & 46 & $\mathbf{F}$ & Girdle & $\begin{array}{l}\text { Both } \\
\text { legs }\end{array}$ & Normal & $\begin{array}{l}\text { Bilateral } \\
\text { loss }\end{array}$ & $\begin{array}{c}\text { Moderate } \\
\text { paraparesis }\end{array}$ & $\uparrow \uparrow$ & $\uparrow$ & None & $\begin{array}{l}\text { Complete } \\
\text { block }\end{array}$ & T.7-8 & Laminectomy & $\begin{array}{l}\text { Partial } \\
\text { recovery }\end{array}$ \\
\hline 3 & 44 & $\mathbf{M}$ & $\begin{array}{l}\text { Back. } \\
\text { Girdle }\end{array}$ & $\begin{array}{l}\text { Left } \\
\text { leg }\end{array}$ & Retention & $\begin{array}{l}\text { Brown- } \\
\text { Séquard }\end{array}$ & $\begin{array}{c}\text { Moderate } \\
\text { monoparesis }\end{array}$ & $\downarrow \uparrow$ & $\uparrow$ & T.9-10 & $\begin{array}{l}\text { Partial } \\
\text { block }\end{array}$ & | T.9-10 & Laminectomy & $\begin{array}{l}\text { Static early. } \\
\text { Died at } \\
2 \text { weeks }\end{array}$ \\
\hline 4 & 58 & $\mathbf{F}$ & None & $\begin{array}{c}\text { Right } \\
\text { leg }\end{array}$ & Normal & $\begin{array}{l}\text { Bilateral } \\
\text { loss }\end{array}$ & $\begin{array}{c}\text { Severe } \\
\text { paraparesis }\end{array}$ & $\uparrow \uparrow$ & $\uparrow$ & None & $\begin{array}{l}\text { Partial } \\
\text { block }\end{array}$ & T.11-12 & Laminectomy & Paraplegia \\
\hline 5 & 66 & $\mathbf{M}$ & $\begin{array}{l}\text { Girdle. } \\
\text { Both legs }\end{array}$ & $\begin{array}{l}\text { Both } \\
\text { legs }\end{array}$ & Normal & $\begin{array}{l}\text { Bilateral } \\
\text { loss }\end{array}$ & $\begin{array}{c}\text { Moderate } \\
\text { paraparesis }\end{array}$ & $\uparrow \uparrow$ & $\uparrow$ & None & $\begin{array}{l}\text { Partial } \\
\text { block }\end{array}$ & $|\mathrm{T} .11-12|$ & Laminectomy & Unchanged \\
\hline 6 & 38 & $\mathbf{M}$ & Both legs & $\begin{array}{l}\text { Both } \\
\text { legs }\end{array}$ & Hesitancy & $\begin{array}{l}\text { Bilateral } \\
\text { loss }\end{array}$ & $\underset{\text { paraparesis }}{\text { Mild }}$ & $\uparrow \uparrow$ & $\uparrow$ & $\begin{array}{l}\text { T.6-7 } \\
\text { T.7-8 }\end{array}$ & $\begin{array}{l}\text { Partial } \\
\text { block }\end{array}$ & T.7-8 & $\begin{array}{l}\text { Lateral } \\
\text { rhachotomy }\end{array}$ & $\begin{array}{c}\text { Full } \\
\text { recovery }\end{array}$ \\
\hline 7 & 61 & $\mathbf{M}$ & $\begin{array}{l}\text { Back. } \\
\text { Right } \\
\text { leg }\end{array}$ & $\begin{array}{l}\text { Both } \\
\text { legs }\end{array}$ & Normal & $\begin{array}{l}\text { Bilateral } \\
\text { loss }\end{array}$ & $\begin{array}{c}\text { Moderate } \\
\text { paraparesis }\end{array}$ & $\uparrow \uparrow$ & $\uparrow$ & None & $\begin{array}{l}\text { Partial } \\
\text { block }\end{array}$ & T.9-10 & Laminectomy & $\begin{array}{l}\text { Early: } \\
\text { improved. } \\
\text { Late: } \\
\text { tetraparesis }\end{array}$ \\
\hline 8 & 44 & $\mathbf{M}$ & None & $\begin{array}{l}\text { Both } \\
\text { legs }\end{array}$ & Normal & $\begin{array}{l}\text { Bilateral } \\
\text { loss }\end{array}$ & \begin{tabular}{|c} 
Mild \\
paraparesis
\end{tabular} & $\uparrow \uparrow$ & $\uparrow$ & None & $\begin{array}{l}\text { Partial } \\
\text { block }\end{array}$ & T.8-9 & Laminectomy & $\begin{array}{c}\text { Partial } \\
\text { recovery }\end{array}$ \\
\hline 9 & 33 & $\mathbf{M}$ & Back & $\begin{array}{l}\text { Both } \\
\text { legs }\end{array}$ & Retention & $\begin{array}{l}\text { Bilateral } \\
\text { loss }\end{array}$ & Paraplegia & Absen & & $\begin{array}{c}\text { T.8-9 } \\
\text { T.9-10 } \\
\text { T.10-11 }\end{array}$ & $\begin{array}{l}\text { Partial } \\
\text { block }\end{array}$ & T.8-9 & $\begin{array}{l}\text { Lateral } \\
\text { rhachotomy }\end{array}$ & Unchanged \\
\hline 10 & 51 & $\mathbf{F}$ & $\begin{array}{c}\text { Back. } \\
\text { Both legs }\end{array}$ & $\begin{array}{l}\text { Left } \\
\text { leg }\end{array}$ & Normal & $\underset{\substack{\text { Bilateral } \\
\text { loss }}}{ }$ & $\begin{array}{c}\text { Moderate } \\
\text { monoparesis }\end{array}$ & $\uparrow \uparrow$ & $\uparrow$ & None & $\begin{array}{l}\text { Partial } \\
\text { block }\end{array}$ & T.8-9 & $\begin{array}{l}\text { Lateral } \\
\text { rhachotomy }\end{array}$ & $\begin{array}{c}\text { Partial } \\
\text { recovery }\end{array}$ \\
\hline 11 & 49 & $\mathbf{M}$ & Both legs & $\begin{array}{c}\text { Both } \\
\text { legs }\end{array}$ & Hesitancy & $\begin{array}{c}\text { Bilateral } \\
\text { loss }\end{array}$ & $\begin{array}{c}\text { Moderate } \\
\text { paraparesis }\end{array}$ & $\uparrow \uparrow$ & $\uparrow$ & 4 levels & $\begin{array}{l}\text { Partial } \\
\text { block }\end{array}$ & T.8-9 & Laminectomy & Paraplegia \\
\hline 12 & 55 & $\mathbf{M}$ & None & $\begin{array}{l}\text { Both } \\
\text { legs }\end{array}$ & Hesitancy & $\begin{array}{c}\text { Bilateral } \\
\text { loss }\end{array}$ & $\begin{array}{c}\text { Moderate } \\
\text { paraparesis }\end{array}$ & $\uparrow \uparrow$ & $\uparrow$ & $\begin{array}{l}\text { T.7-8 } \\
\text { T.8-9 }\end{array}$ & $\begin{array}{c}\text { Complete } \\
\text { block }\end{array}$ & T.8-9 & $\begin{array}{c}\text { Lateral } \\
\text { rhachotomy }\end{array}$ & $\begin{array}{c}\text { Full } \\
\text { recovery }\end{array}$ \\
\hline 13 & 45 & $\mathbf{M}$ & Back & $\begin{array}{l}\text { Left } \\
\text { leg }\end{array}$ & Normal & $\begin{array}{c}\text { Bilateral } \\
\text { loss }\end{array}$ & Normal & $\downarrow \downarrow$ & $\downarrow$ & T.9-10 & $\begin{array}{l}\text { Partial } \\
\text { block }\end{array}$ & T.9-10 & $\begin{array}{c}\text { Lateral } \\
\text { rhachotomy }\end{array}$ & Improved \\
\hline 14 & 47 & $\mathbf{M}$ & Left leg & $\underset{\text { leg }}{\text { Right }}$ & Hesitancy & $\begin{array}{l}\text { Brown- } \\
\text { Séquard }\end{array}$ & $\begin{array}{l}\text { Mild left } \\
\text { paresis }\end{array}$ & $\downarrow \uparrow$ & $\uparrow$ & T.6-7 & $\begin{array}{l}\text { Partial } \\
\text { block }\end{array}$ & T.6-7 & $\begin{array}{c}\text { Lateral } \\
\text { rhachotomy }\end{array}$ & Improved \\
\hline 15 & 56 & $\mathbf{F}$ & None & $\begin{array}{l}\text { Both } \\
\text { legs }\end{array}$ & Urgency & $\begin{array}{c}\text { Bilateral } \\
\text { loss }\end{array}$ & \begin{tabular}{|c} 
Mild \\
paraparesis
\end{tabular} & $\uparrow \uparrow$ & $\uparrow$ & T.7-8 & $\begin{array}{c}\text { Complete } \\
\text { block }\end{array}$ & T.7-8 & $\begin{array}{l}\text { Lateral } \\
\text { rhachotomy }\end{array}$ & Improved \\
\hline 16 & 33 & $\mathbf{M}$ & $\begin{array}{l}\text { Back. } \\
\text { Girdle }\end{array}$ & $\begin{array}{l}\text { Left } \\
\text { leg }\end{array}$ & Normal & $\begin{array}{l}\text { Brown- } \\
\text { Séquard }\end{array}$ & $\begin{array}{c}\text { Mild left } \\
\text { paresis }\end{array}$ & $\downarrow \downarrow$ & $\downarrow$ & None & $\begin{array}{l}\text { Partial } \\
\text { block }\end{array}$ & T.7-8 & Laminectomy & Worse \\
\hline 17 & 45 & $\mathbf{M}$ & Girdle & $\underset{\text { leg }}{\text { Right }}$ & Normal & $\begin{array}{l}\text { Brown- } \\
\text { Séquard }\end{array}$ & $\begin{array}{l}\text { Mild right } \\
\text { paresis }\end{array}$ & $\uparrow \uparrow$ & $\uparrow$ & T.9-10 & $\begin{array}{c}\text { Complete } \\
\text { block }\end{array}$ & T.9-10 & Laminectomy & Improved \\
\hline 18 & 62 & $\mathbf{M}$ & $\begin{array}{l}\text { Back. } \\
\text { Left leg }\end{array}$ & $\begin{array}{l}\text { Left } \\
\text { leg }\end{array}$ & Normal & Normal & $\begin{array}{c}\text { Moderate } \\
\text { paraparesis }\end{array}$ & $\uparrow \uparrow$ & $\uparrow$ & None & $\underset{\text { block }}{\text { Complete }}$ & $\mid$ T.11-12 & Laminectomy & $\underset{\text { recovery }}{\text { Partial }}$ \\
\hline 19 & 41 & $\mathbf{M}$ & Back & $\begin{array}{l}\text { Both } \\
\text { legs }\end{array}$ & Normal & $\begin{array}{c}\text { Bilateral } \\
\text { loss }\end{array}$ & $\begin{array}{c}\text { Mild } \\
\text { paraparesis }\end{array}$ & $\uparrow \uparrow$ & $\uparrow$ & None & $\begin{array}{l}\text { Partial } \\
\text { block }\end{array}$ & T.10-11 & Laminectomy & Worse \\
\hline 20 & 48 & $\mathbf{F}$ & $\begin{array}{l}\text { Back. } \\
\text { Both legs }\end{array}$ & $\begin{array}{l}\text { Both } \\
\text { legs }\end{array}$ & Retention & $\begin{array}{c}\text { Bilateral } \\
\text { loss }\end{array}$ & Paraplegia & $\uparrow \uparrow$ & $\uparrow$ & None & $\begin{array}{c}\text { Complete } \\
\text { block }\end{array}$ & T.9-10 & Laminectomy & Unchanged \\
\hline 21 & 52 & $\mathbf{F}$ & Back & None & Normal & Normal & Normal & $\downarrow \downarrow$ & $\downarrow$ & None & $\begin{array}{c}\text { Complete } \\
\text { block }\end{array}$ & T.9-10 & Laminectomy & $\begin{array}{c}\text { Slightly } \\
\text { worse }\end{array}$ \\
\hline 22 & 50 & $\mathbf{M}$ & None & $\begin{array}{l}\text { Both } \\
\text { legs }\end{array}$ & Normal & $\begin{array}{c}\text { Bilateral } \\
\text { loss }\end{array}$ & $\begin{array}{c}\text { Moderate } \\
\text { paraparesis }\end{array}$ & $\mathbb{1} 1$ & 1 & None & $\begin{array}{l}\text { Partial } \\
\text { block }\end{array}$ & T.5-6 & Laminectomy & $\begin{array}{c}\text { Slightly } \\
\text { worse }\end{array}$ \\
\hline
\end{tabular}


This error was corrected at operation and the patient subsequently did well. For either operation the patients were placed prone, with the thoracic and lumbar spine flexed, the hips flexed 30 degrees and the knees flexed 90 degrees. Lateral rhachotomy (Fig. 7) was performed through a curved incision extending two to three vertebrae above and below the lesion. The apex of the curve was 8 centimetres from the midline. After incision of the deep fascia the whole flap was reflected medially to the spinous processes. The lateral group of spinal muscles was divided transversely at the level of the disc protrusion. The rib concerned was stripped subperiosteally from its angle to the transverse process and either the rib above or the rib below was similarly stripped. The pleura was swept away and retracted. The intercostal nerve was identified and traced to its bony exit. The proximal end of the rib together with the transverse process was then removed. The spinal exit foramen was enlarged by nibbling at both superior and inferior pedicles and anteriorly into the disc space. At this stage the theca was often visible. The intercostal nerve was sometimes divided to improve access. The disc space was cleared by gentle nibbling and the disc protrusion was then removed, again by gentle nibbling. In only one of the seven patients was a pneumothorax produced and this was rapidly absorbed.

Laminectomy (Fig. 8) was performed by removing the posterior elements, including the spinal processes and laminae, of two or three vertebrae. In eleven of the fifteen patients the disc was exposed transdurally; in four patients exposure was extradural. In ten patients the disc was nibbled away; in five patients the disc was not removed, usually because it actively eroded into the theca and on one occasion into the spinal cord itself.

Pathology-Although the spinal canal enlarges at T.11 and T.12 to contain the cord swelling produced by the lumbar enlargement, there is little extradural space, and the comparatively small disc protrusions may have pronounced effects. Dommisse (1974) showed that the thoracic spinal canal was consistently at its narrowest in that part of the vertebral column extending from T.4 to T.9. He further showed that the narrow zone of the spinal canal corresponded almost exactly with that part of the cord to which the blood supply was least profuse. The disc protrusion itself has been shown to vary in consistency from a soft almost gelatinous swelling to a bony hard excrescence. The protrusion may be under such pressure that erosion of the dura mater and indeed true erosion of the spinal cord occur (Fisher 1965; Reeves and Brown 1968). Damage to the cord may be either by direct pressure or by secondary vascular effects. In several patients submitted to laminectomy, when the cord is more fully exposed, there was evidence of irreparable damage manifest in one case by gross cystic change, and in others frank bruising or bluish discoloration of the cord.

\section{RESULTS}

Patients have been followed up for a period ranging from three months to twelve years, the median duration being three and three-quarter years. It is noteworthy that the early post-operative clinical appearance was not necessarily a guide to the final outcome. Three patients who subsequently improved considerably were found initially to have an almost complete paraplegia. The greatest neurological recovery commonly occurred within the first six weeks, but some patients continued to show improvement for up to two years.
In assessing the results of operation, consideration was paid to pain relief, improvement of power, sensation and sphincter function, together with improvement in walking and the resumption of previous occupation. An overall assessment was then made. Irrespective of the surgical approach back pain when present has been improved. One patient developed pain as the result of the laminectomy which was unaltered over a period of five years. It was apparent that sensory recovery was almost always incomplete, even when motor recovery was full. Motor recovery, moreover, was always in advance of sensory recovery.

Of the seven patients submitted to lateral rhachotomy, six showed improvement and one was unchanged (Table I). The patient unaltered by operation was the thirty-three-year-old man with acute flaccid paraplegia. No patient complained of residual pain, but most had some degree of sensory impairment. Only the paraplegic patient required long-term catheter drainage. No patient suffered from intercostal neuralgia.

Fifteen patients were submitted to laminectomy. Six of these were improved; two were unaltered and six deteriorated. One patient died two weeks after operation from a massive pulmonary embolus. His clinical state at that stage was unchanged. The paraplegic patient on whom laminectomy was performed was similarly unaltered. One patient, initially with a moderate paraparesis, became paraplegic after laminectomy. The patient with achondroplasia initially made a partial recovery after laminectomy, but subsequently developed spastic tetraparesis complicating a cervical disc protrusion. Two patients complained of severe residual pain: in one this was at the site of laminectomy, in the other persistent girdle pain occurred.

Of the twenty-one surviving patients, eleven were subsequently able to walk unaided, six were able to walk only with walking aids and four were unable to walk. In the lateral rhachotomy group, with the exception of the paraplegic patient, all patients were subsequently able to walk without walking aids.

\section{DISCUSSION}

An analysis of the figures suggests that each orthopaedic surgeon is likely to see three to four patients with prolapsed thoracic intervertebral discs in his professional lifetime. The establishment of a diagnosis may prove difficult because the symptoms are protean and may mimic a wide variety of disorders. Abbott and Retter (1956) quoted examples of patients being thought to have cardiac, pulmonary or abdominal disease. Neurosis and hysteria had similarly been diagnosed. One patient we reviewed had been thought to be suffering from disseminated sclerosis. Even when the clinical situation is correctly attributed to compression within the spinal canal, other causes of compression must be excluded. The demonstration of calcification in the disc space may well 
provide a valuable pointer to the diagnosis, particularly as the site of predilection for calcification appears to be at the level of the disc prolapse. Certainly, positive contrast myelography has been the mainstay of diagnosis, and the fact that a positive pre-operative diagnosis was established in these patients reflects the expertise in performing and interpreting myelographs (Thomson 1966). It seems that air myelography will play an increasing part in the establishment of the correct diagnosis and may indeed become a routine investigation in all patients suspected of having a prolapsed intervertebral thoracic disc.
Although this is a retrospective analysis, and the numbers of patients are small, it does seem that lateral rhachotomy carries a significant advantage over thoracic laminectomy. It is essential that the pre-operative diagnosis be correct, as the thecal exposure is restricted. This relative disadvantage, however, is more than compensated for by the direct access offered to the disc protrusion and the minimal thecal mobilisation necessary. Certainly, no patient was made worse by lateral rhachotomy and this contrasts most favourably with the morbidity associated with thoracic laminectomy.

We wish to thank Mr L. S. Walsh, Mr A. E. Richardson and Mr D. N. Grant for permission to record their patients. We further wish to thank them and $\mathrm{Mr} \mathrm{D}$. R. Sweetnam for their invaluable advice. We are grateful to $\mathrm{Mr} \mathrm{P}$. Drury for his illustrations, and to the photographic department of the Middlesex Hospital.

\section{REFERENCES}

Abbott, K. H., and Retter, R. H. (1956) Protrusions of thoracic intervertebral disks. Neurology, Minneapolis, 6, 1-10.

Arseni, C., and Nash, F. (1960) Thoracic intervertebral disc protrusion. Journal of Neurosurgery, 17, 418-430.

Capener, N. (1954) The evolution of lateral rhachotomy. Journal of Bone and Joint Surgery, 36-B, 173-179.

Carson, J., Gumpert, J., and Jefferson, A. (1971) Diagnosis and treatment of thoracic intervertebral disc protrusions. Journal of Neurology, Neurosurgery and Psychiatry, 34, 68-77.

Chesterman, P. J. (1964) Spastic paraplegia caused by sequestrated thoracic intervertebral disc. Proceedings of the Royal Society of Medicine, 57, 87-88.

Crafoord, C., Hiertonn, T., Lindblom, K., and Olsson, S.-E. (1958) Spinal cord compression caused by a protruded thoracic disc. Report of a case treated with antero-lateral fenestration of the disc. Acta orthopaedica Scandinavica, 28, $103-107$.

Dommisse, G. F. (1974) The blood supply of the spinal cord. Journal of Bone and Joint Surgery, 56-B, 225-235.

Fisher, R. G. (1965) Protrusions of thoracic disc. The factor of herniation through the dura mater. Journal of Neurosurgery, $22,591-593$.

Haley, J. C., and Perry, J. H. (1950) Protrusions of intervertebral discs. Study of their distribution, characteristics and effects on the nervous system. American Journal of Surgery, 80, 394-404.

Hawk, W. A. (1936) Spinal compression caused by ecchondrosis of the intervertebral fibrocartilage: with a review of the recent literature. Brain, 59, 204-224.

Hulme, A. (1960) The surgical approach to thoracic intervertebral disc protrusions. Journal of Neurology, Neurosurgery and Psychiatry, 23, $133-137$

Kroll, F.-W., and Reiss, E. (1951) Der thorakale Bandscheibenprolaps. Deutsche medizinische Wochenschrift, 76, $600-603$.

Logue, V. (1952) Thoracic intervertebral disc prolapse with spinal cord compression. Journal of Neurology, Neurosurgery and Psychiatry, $15,227-241$

Love, J. G., and Keifer, E. J. (1950) Root pain and paraplegia due to protrusions of thoracic intervertebral disks. Journal of Neurosurgery, 7, 62-69.

Love, J. G., and Schorn, V. G. (1965) Thoracic-disk protrusions. Journal of the American Medical Association, 191, 627-631.

Ménard, V. (1900) Étude Pratique sur le Mal de Pott. Paris: Masson et Cie.

Middleton, G. S., and Teacher, J. H. (1911) Injury of the spinal cord due to rupture of an intervertebral disc during muscular effort. Glasgow Medical Journal, 76, 1-6.

Mixter, W. J., and Barr, J. S. (1934) Rupture of the intervertebral disc with involvement of the spinal canal. New England Journal of Medicine, 211, 210-215.

Mäller, R. (1951) Protrusion of thoracic intervertebral disks with compression of the spinal cord. Acta medica Scandinavica, 139, 90-104.

Peck, F. C., Jun. (1957) A calcified thoracic intervertebral disk with herniation and spinal cord compression in a child. Journal of Neurosurgery, 14, 105-109.

Perot, P. L., Jun., and Munro, D. D. (1969) Transthoracic removal of midline thoracic disc protrusions causing spinal cord compression. Journal of Neurosurgery, 31, 452-458.

Ransohoff, J., Spencer, F., Siew, F., and Gage, L., Jun. (1969) Transthoracic removal of thoracic disc. Journal of Neurosurgery, $31,459-461$.

Reeves, D. L., and Brown, H. A. (1968) Thoracic intervertebral disc protrusion with spinal cord compression. Journal of Neurosurgery, $28,24-28$.

Seddon, H. J. (1935) Pott's paraplegia - prognosis and treatment. British Journal of Surgery, 22, 769-799.

Svien, H. J., and Karavitis, A. L. (1954) Multiple protrusions of intervertebral disks in the upper thoracic region. Proceedings of the Staff Meetings of the Mayo Clinic, 29, 375-378.

Thomson, J. L. G. (1966) Myelography in dorsal disc protrusion. Acta radiologica Diagnosis, 5, 1140-1146. 